\title{
GENDER GAP IN EDUCATION: THE CASE OF EASTERN \& SOUTH- EASTERN REGIONS OF AFGHANISTAN
}

\author{
Najibullah Totakhiel ${ }^{*}{ }^{\circledR}$ \\ ${ }^{* 1}$ Dean, Economics Faculty Paktia University, 2209 Gardez, Afghanistan
}

DOI: https://doi.org/10.29121/granthaalayah.v8.i6.2020.487

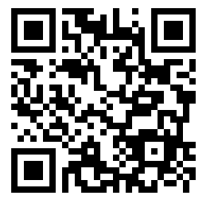

Article Type: Case Study

Article Citation: Najibullah

Totakhiel. (2020). GENDER GAP IN

EDUCATION: THE CASE OF

EASTERN \& SOUTH-EASTERN

REGIONS OF AFGHANISTAN.

International Journal of Research -

GRANTHAALAYAH, 8(6), 202-211.

https://doi.org/10.29121/granthaa

layah.v8.i6.2020.487

Received Date: 09 May 2020

Accepted Date: 28 June 2020

Keywords:

Educational gender gap

Regions

Provinces

Students

Teachers

Schools

Male

Female

\section{ABSTRACT}

This research aims to find the size of the gender gap in education in the ten provinces of the Eastern Region (ER) and the South-Eastern Region (SER) of Afghanistan. Based on the World Economic Forum (WEF) approach to the gender gap, the study measures the educational gender gap index (EGGI) at both the regional and provincial level.

The study found that the regional EGGI is 0.30 . This means that $70 \%$ of the gender gap remains. The EGGI in the ER is 0.35 , while in the SER it is 0.25 , which means that $65 \%$ and $75 \%$ of the gender gap remains in the ER and the SER respectively. Thus, the gap is smaller in the ER than in the SER. At the provincial level, the best performing province is Nangarhar, where $42 \%$ of the gap has been closed. The worst performing province is Wardak, where only $15 \%$ of the gap has been closed.

Of the six sub-indexes of the EGGI which were calculated from the primary data, the largest gender disparity is in the enrolment in tertiary level education, which has a gap of $69 \%$. The second largest gap is $55 \%$ for the number of male and female schools. Both middle school enrolment and teacher gender ratio have similar sized gaps of $53 \%$. The gaps for enrolment in primary education and secondary education are lower, at $30 \%$ and $43 \%$ respectively. The gap between the male and female studentteacher ratios is $73.6 \%$. Furthermore, there is a $67.7 \%$ gap in literacy rate between males and females across the country.

\section{INTRODUCTION}

\subsection{DESCRIPTION OF DATA}

Both primary and secondary data were used in this research. The core of this research used primary data, and secondary data were used mainly to construct the theoretical framework. To obtain the primary data, a structured questionnaire was distributed to the ten provinces of the Eastern Region (ER) and the South-Eastern Region (SER) of Afghanistan.

Figure 1 shows the ten provinces of these two regions in which this research was conducted: Nangarhar, Laghman, Kunar and Nuristan in the ER, and Paktia, Logar, Paktika, Khowst, Ghazni and Wardak in the SER. The data were collected from the educational directorates of these provinces.

(C) 2020 The Author(s). This is an open access article distributed under the terms of the Creative Commons Attribution License, which permits unrestricted use, distribution, and reproduction in any medium, provided the original author and source are credited. 


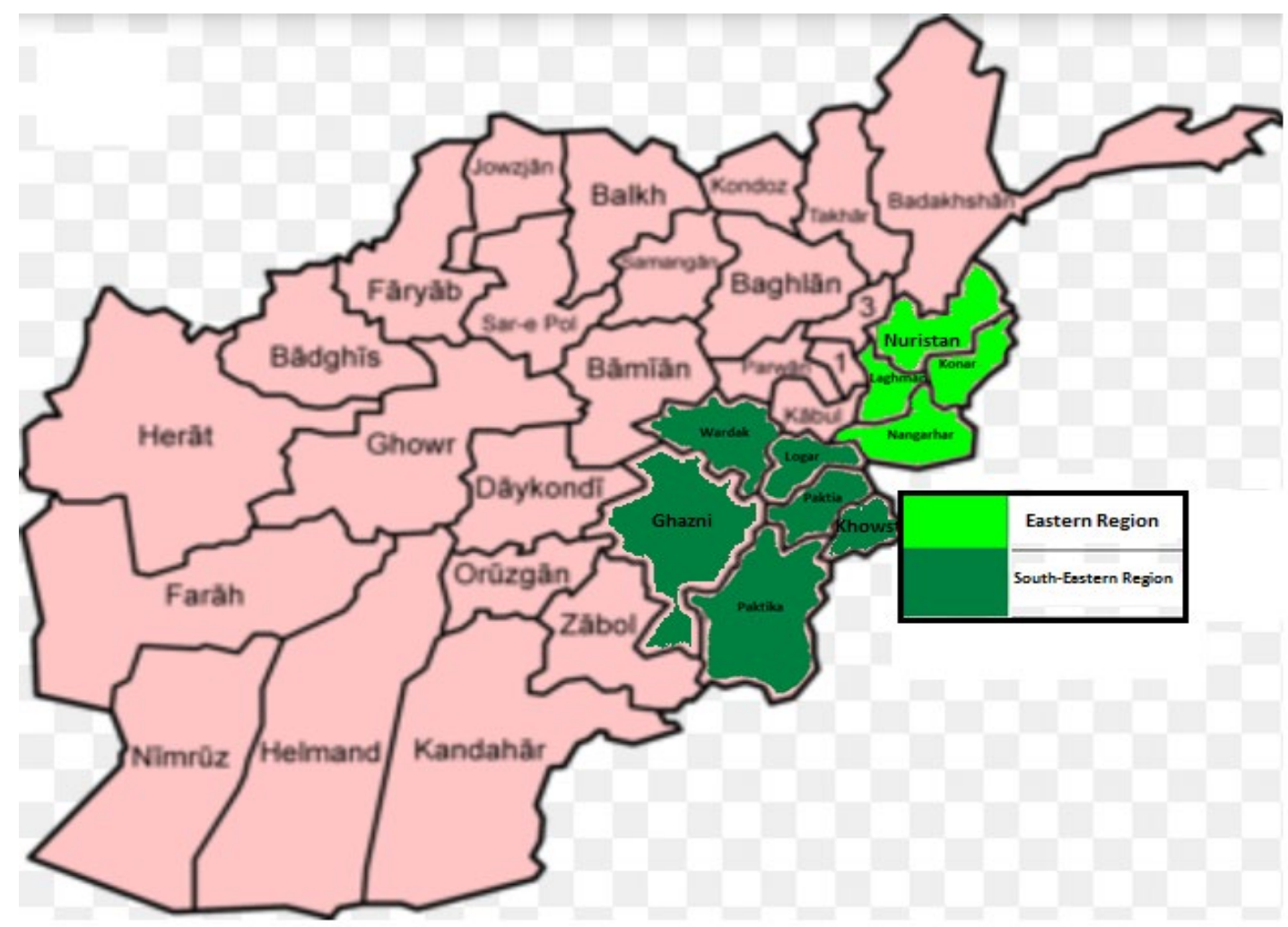

Figure 1: A map of Afghanistan showing the provinces of the ER and SER studied

According to the most recent data, Afghanistan's population is 38.04 million, with $51.7 \%$ of the population male and the remaining $48.3 \%$ female. The combined population of the ER and the SER (where we conducted this study) is 7,208,211 (World population, 2019).

Figures 2 and 3 show the data collected on the number of male and female students and teachers in these two regions. There are $2,575,494$ students in the two regions, and $33 \%(855,547)$ of them are female. Furthermore, there are 48,337 teachers, of which $12 \%(5,647)$ are female.

Figure 2: Gender of students in both ER \& SER

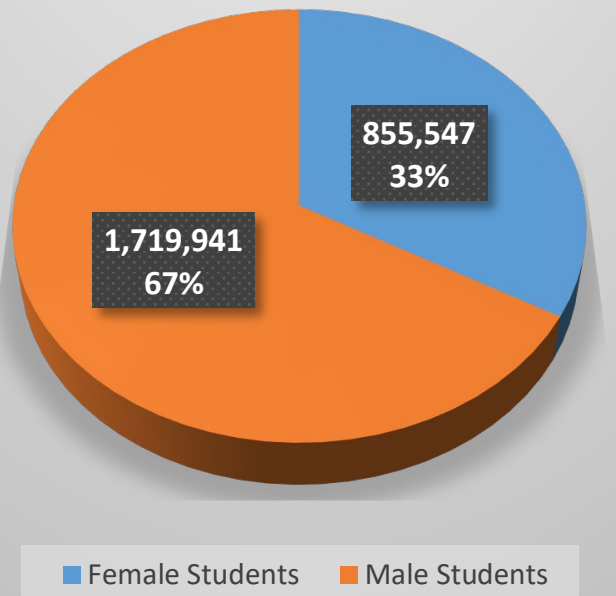

Figure 3: Gender of teachers in both ER \& SER

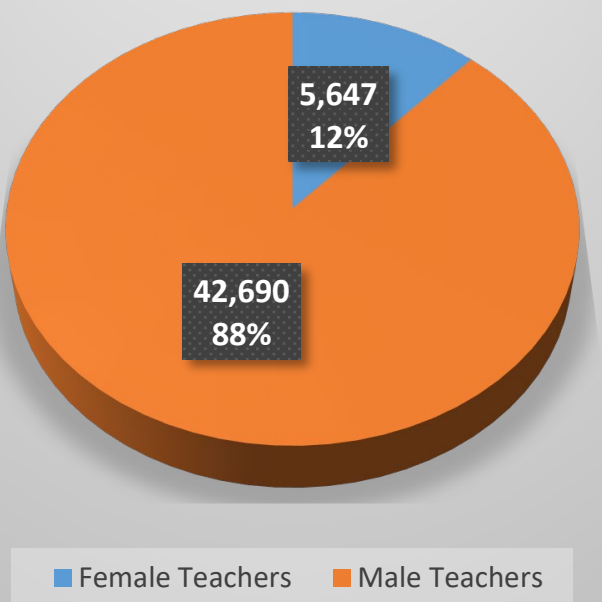

Source: author computation 
Figure 4 shows the numbers and percentages of students enrolled in school in the ER and the SER of Afghanistan. On average, $16 \%$ of girls and $31 \%$ of boys are enrolled in primary education, $7 \%$ of girls and $12 \%$ of boys are enrolled in middle schools, and $9 \%$ of girls and $22 \%$ of boys are enrolled in secondary education. Just $1 \%$ of women and $2 \%$ of men are in teacher training colleges.

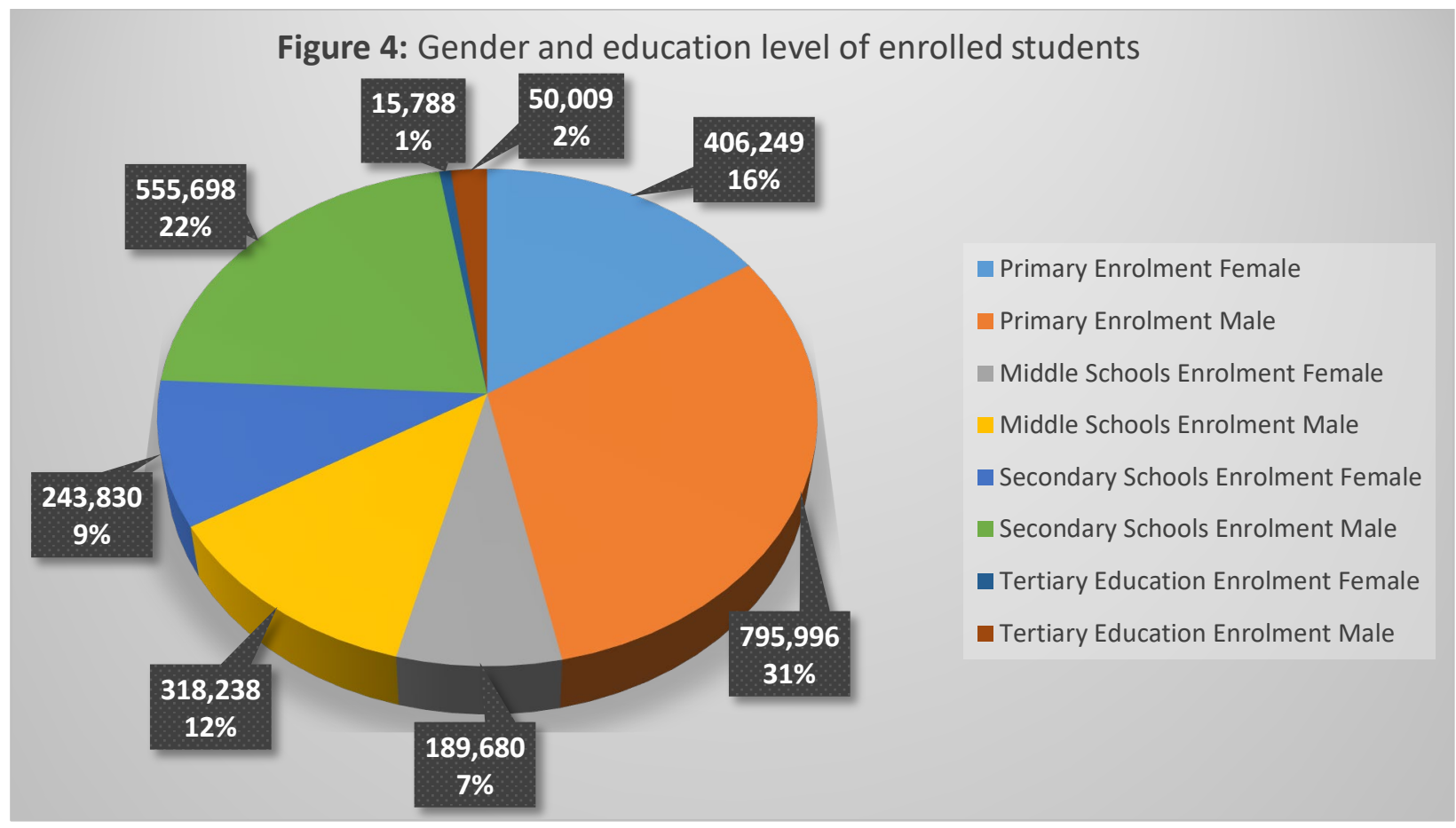

Source: author computation

Children start school at the age of seven in Afghanistan. They study at primary school for six years, middle school for three years and then secondary school for a further three years, so it takes 12 years to complete primary, middle and secondary school in Afghanistan. Tertiary educational is started after completing secondary education. In this research, only tertiary education which consists of two years of study, such as courses at teacher training institutions, was considered.

\section{RESEARCH QUESTION/THEORETICAL CONTEXTUALIZATION}

As a numerical term, gender parity in education means the equal participation of both boys and girls in different areas of education (UNESCO, 2000). Globally, the educational attainment gap is significantly below parity, at $4.4 \%$ (WEF, 2018).

This project aims to measure the magnitude of the persistent gender gap in education across all ten provinces of the two regions. Hence, the research will find scientific answers to the following research questions:

- Which region has a larger gender gap in education (eastern or south-eastern)?

- What disparities exist between male and female students regarding educational attainment in these two regions, and how large are these disparities?

- Which of the ten provinces has the largest and which has the smallest gender gap in education? How are they ranked?

\section{FIELD RESEARCH DESIGN/METHODS OF GATHERING DATA}

This research is designed to quantitatively study the gender gap in education in the provinces of the ER and SER of Afghanistan. The population of the study is the ten provinces of these two regions. The required data was collected through a structured 22-question questionnaire distributed to the public educational directorates of these ten 
provinces. A team of ten data collectors was trained and sent to these provinces to collect certified data from the public educational directorates.

The study is designed to measure the educational gender gap index (EGGI) regionally, as well as in each zone and province separately. Based on the gender gap approach of the World Economic Forum introduced by Hausmann, Tyson and Zahidi, this study measured the EGGI using a weighted mean of six sub-indexes. These six sub-indexes of the EGGI are defined as the following ratios:

- Ratio $\left(\mathrm{R}_{1}\right)$ : number of female schools over male schools

- Ratio $\left(\mathrm{R}_{2}\right)$ : female net primary level enrolment over male value

- Ratio $\left(\mathrm{R}_{3}\right)$ : female net middle level enrolment over male value

- Ratio $\left(\mathrm{R}_{4}\right)$ : female net secondary level enrolment over male value

- Ratio $\left(R_{5}\right)$ : female tertiary level enrolment over male value

- Ratio $\left(\mathrm{R}_{6}\right)$ : number of female teachers over number of male teachers

Due to the unavailability of authentic data on the literacy rate in these provinces, we chose to exclude this from the model and study it separately and across the whole country.

To measure the gender gap in education, the study used a three-step process, outlined below.

Step 1: Convert to ratios. First, all the collected data are converted to female/male ratios. For example, a province where $20 \%$ of teachers are female is assigned a ratio of 20 female teachers $/ 80$ male teachers $=0.25$. The six variables are converted to ratios in this first step to ensure that the index captures the gaps between women and men's attainment levels, rather than the levels themselves.

Step 2: Truncate data at equality benchmark. The ratios are then truncated at the "equality benchmark". This equality benchmark is taken as 1 , meaning equal numbers of men and women, for all six variables. Truncating the data at the equality benchmark for each variable means assigning the same score to a province or region that has reached parity between women and men as to one where women have surpassed men.

Step 3: Calculate sub-indexes and the overall EGGI. The third and last step in the process involves computing the weighted mean of the variables used to calculate the index to create the index scores. Averaging the different variables would implicitly give more weight to the measure that exhibits the greatest variability or standard deviation. We therefore first normalized the variables by equalizing their standard deviations.

For example, standard deviations are calculated for each of the variables. Then we determine what a $1 \%$ change would translate to in terms of standard deviations by dividing 0.01 by the standard deviation for each variable. These six values are then used as weights to calculate the weighted average of the six variables. This way of weighting the variables essentially allows us to make sure that each variable has the same relative impact on the index.

\section{RESULTS}

The educational gender gap was computed for both regions, as well as for each of the provinces of these regions. Table 1 shows that there is still a gender gap of $70 \%$ in education in these two regions.

The Educational Gender Gap Index (EGGI) for both regions is approximately 30\%. This means that there is still a $70 \%$ gap yet to be closed. Table 1 shows the procedure used to compute the EGGI and its sub-indexes.

Table 1: Computation of the regional gender gap in education

\begin{tabular}{|c|c|c|c|c|c|c|}
\hline $\begin{array}{c}\text { Abb } \\
\text { r. }\end{array}$ & Ratio & Mean & $\begin{array}{l}\text { Std. } \\
\text { dev. }\end{array}$ & $\begin{array}{l}\text { Std. dev. per } 1 \% \\
\text { change }\end{array}$ & $\begin{array}{c}\text { Weig } \\
\text { ht }\end{array}$ & $\begin{array}{l}\text { Mean } \times \\
\text { weight }\end{array}$ \\
\hline $\mathrm{R} 1$ & Ratio: female schools over male schools & 0.414 & 0.314 & 0.032 & $\begin{array}{c}0.10 \\
9\end{array}$ & 0.045 \\
\hline $\mathrm{R} 2$ & $\begin{array}{l}\text { Ratio: female net primary level enrolment } \\
\text { over male value }\end{array}$ & 0.627 & 0.307 & 0.033 & $\begin{array}{c}0.11 \\
1\end{array}$ & 0.070 \\
\hline R3 & $\begin{array}{l}\text { Ratio: female net middle level enrolment } \\
\text { over male value }\end{array}$ & 0.515 & 0.372 & 0.027 & $\begin{array}{c}0.09 \\
2\end{array}$ & 0.047 \\
\hline $\mathrm{R} 4$ & $\begin{array}{l}\text { Ratio: female net secondary level enrolment } \\
\text { over male value }\end{array}$ & 0.308 & 0.185 & 0.054 & $\begin{array}{c}0.18 \\
4\end{array}$ & 0.057 \\
\hline
\end{tabular}


Najibullah Totakhiel

\begin{tabular}{|c|l|c|c|c|c|c|} 
R5 & $\begin{array}{l}\text { Ratio: female tertiary level enrolment over } \\
\text { male value }\end{array}$ & 0.411 & 0.450 & 0.022 & 0.07 & 0.031 \\
\hline R6 & Ratio: female teachers over male teachers & 0.110 & 0.080 & 0.125 & 0.42 & 0.047 \\
\hline & & & & & 1 & 0.297 \\
\hline
\end{tabular}

Source: author computation

Figure 5 shows that across the six sub-indexes, enrolment in tertiary level education has the largest gender gap of $69 \%$. The second largest gap is $55 \%$ for the number of male and female schools. Similarly, there is a $53 \%$ gap for both middle school enrolment and the teacher gender ratio. The gaps in secondary education and primary education enrolment are lower, at $43 \%$ and $30 \%$ respectively.

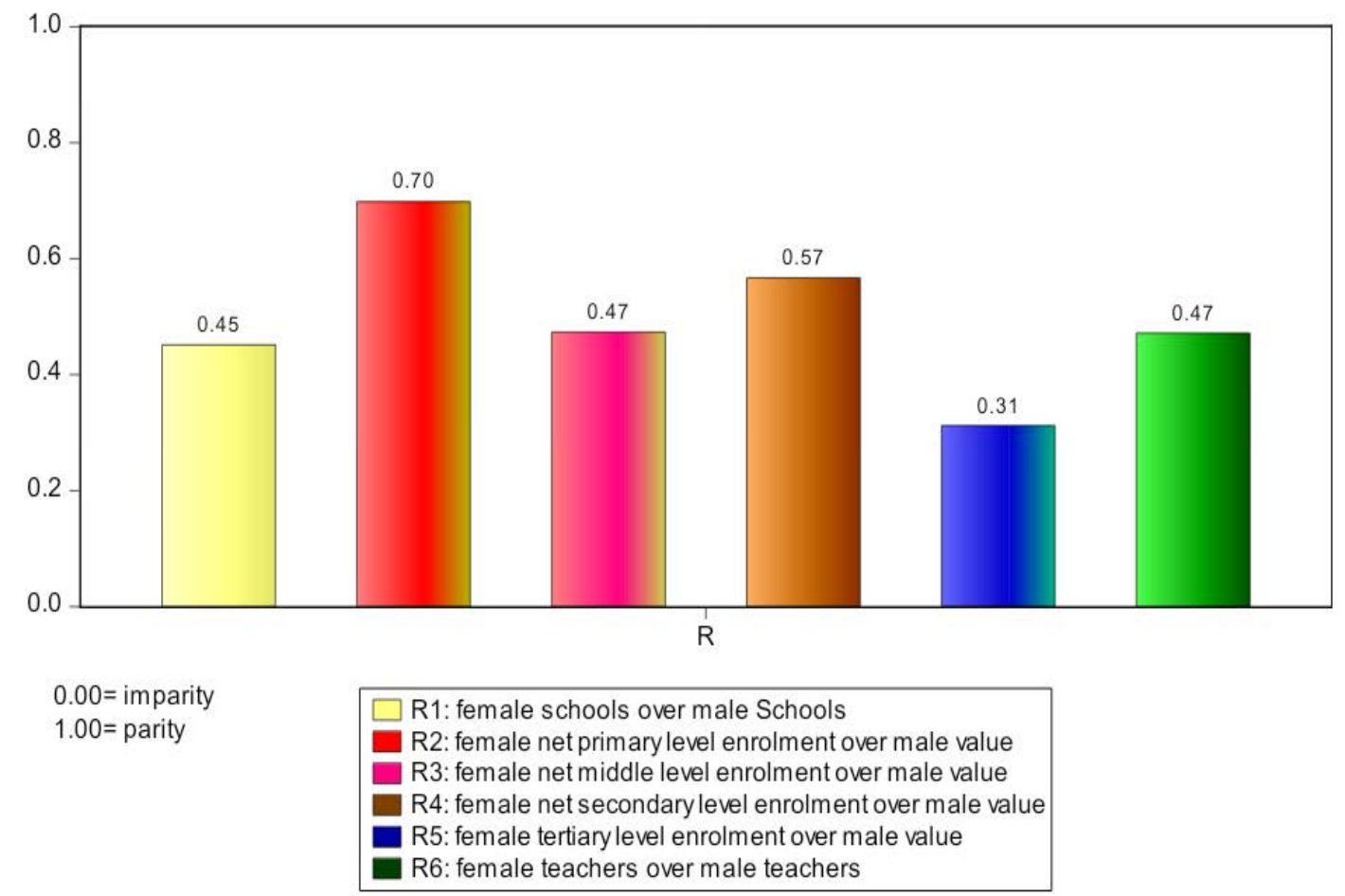

Figure 5: The sub-indexes of the regional gender gap in education

Source: author computation

Table 2: Computation of the educational gender gap for each province and region

\begin{tabular}{|c|c|c|c|c|c|c|}
\hline Province & Mean & Std. dev. & Std. dev. per 1\% change & Weight & Mean $\times$ weight & $\begin{array}{c}\text { Scores } \\
\text { (weighted mean) }\end{array}$ \\
\hline Nangarhar & 0.436 & 0.186 & 0.054 & 0.096 & 0.0418 & 0.418 \\
\hline Kunar & 0.535 & 0.319 & 0.031 & 0.056 & 0.0299 & 0.299 \\
\hline Laghman & 0.445 & 0.217 & 0.046 & 0.082 & 0.0365 & 0.365 \\
\hline Nuristan & 0.634 & 0.336 & 0.030 & 0.053 & 0.0336 & 0.336 \\
\hline Paktia & 0.182 & 0.126 & 0.080 & 0.142 & 0.0257 & 0.257 \\
\hline Logar & 0.274 & 0.147 & 0.068 & 0.121 & 0.0332 & 0.332 \\
\hline Paktika & 0.067 & 0.073 & 0.137 & 0.243 & 0.0163 & 0.163 \\
\hline Khowst & 0.233 & 0.130 & 0.077 & 0.137 & 0.0319 & 0.319 \\
\hline Ghazni & 0.750 & 0.513 & 0.019 & 0.035 & 0.0260 & 0.260 \\
\hline Wardak & 0.421 & 0.498 & 0.020 & 0.036 & 0.0151 & 0.151 \\
\hline & & & & 1 & & \\
\hline
\end{tabular}

Source: author 
Table 2 shows the computational process for determining the educational gender gap index (EGGI) for each province of the two regions. The size of the gap for each region, based on the weighed means, is presented in Figure 6, which shows that the gap is larger in the SER than in the ER.

Figure 6 shows the regional EGGI for both the ER and the SER. The regional EGGI is 0.30 . This means that $70 \%$ of the gap is yet to be closed. The EGGI in the ER is 0.35, while in the SER it is 0.25 . This means there is a $65 \%$ gap in the ER and a 75\% gap in the SER. Thus, the gap is smaller in the ER than in the SER.

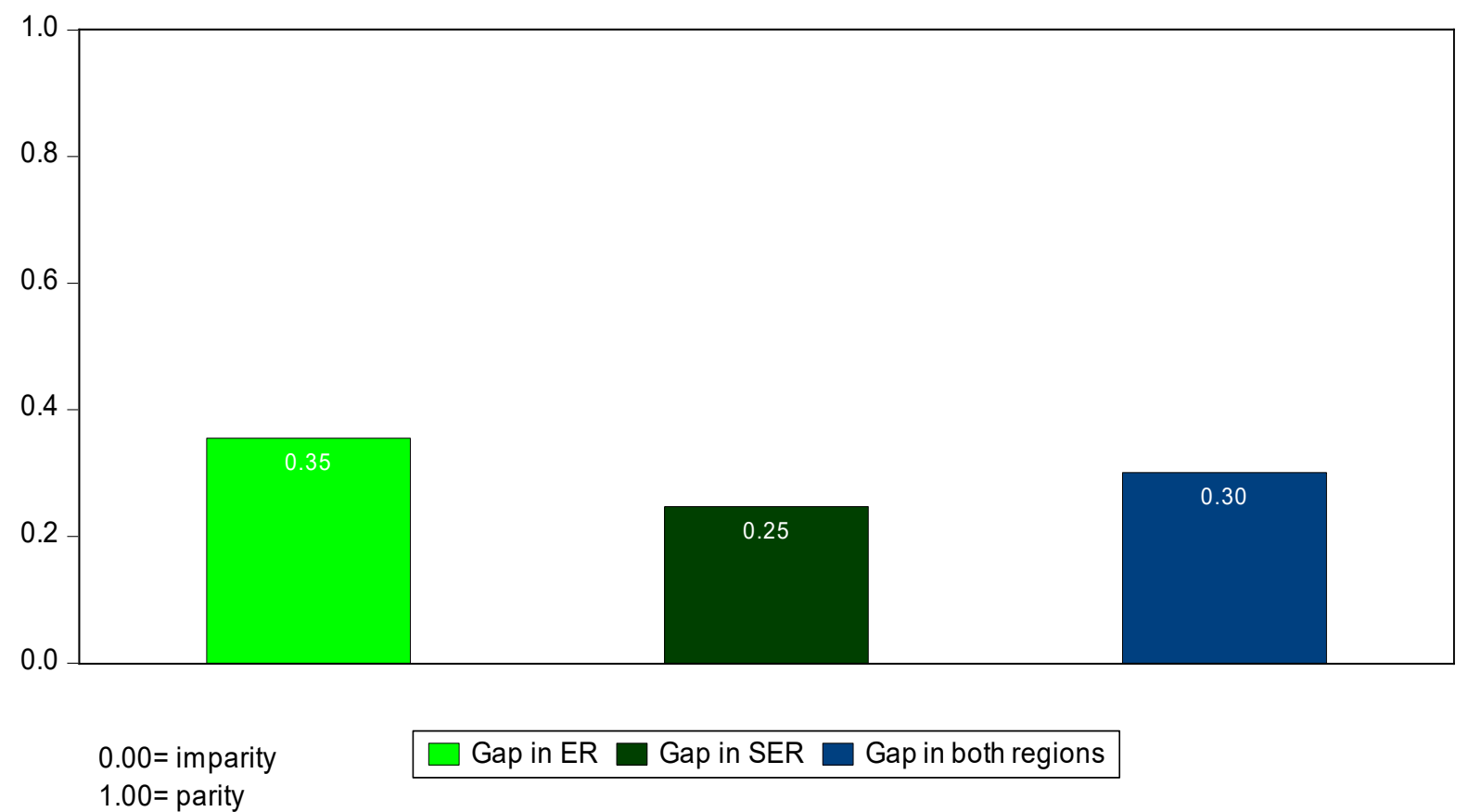

Source: author

Figure 6: EGGI for the ER and SER of Afghanistan

Figure 7 shows the provincial profiles of the gap for the ER. As can be seen, Nangarhar has the smallest gender gap, with a weighted mean of $41.8 \%$. Laghman has the second smallest, with $36.5 \%$ of the gap having been bridged. Nuristan, where $33.3 \%$ of the gap has been closed, is in third position. Kunar has the largest gender gap in the ER, with a weighted mean of $29.9 \%$ and therefore $70.1 \%$ of the gap yet to be closed.

NANGARHAR

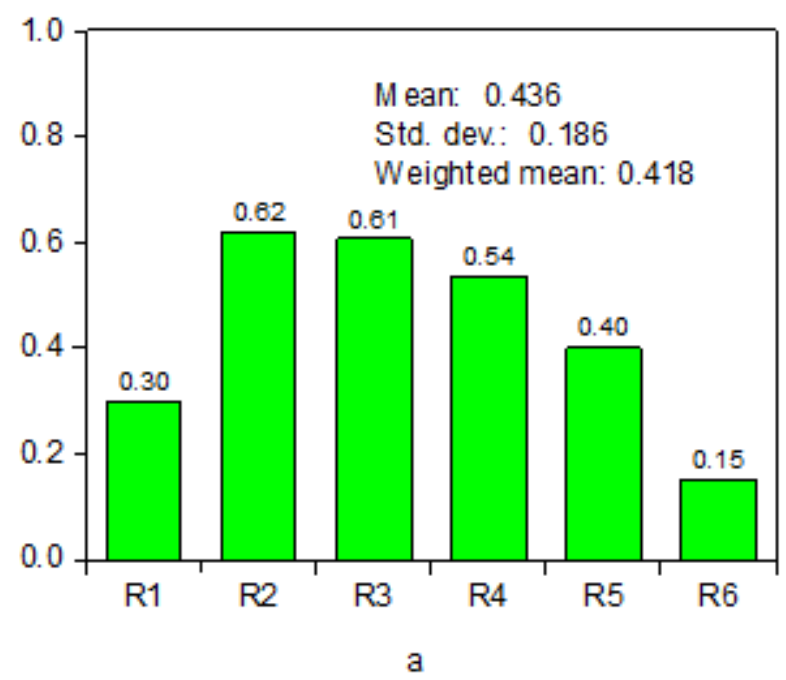

LAGHMAN

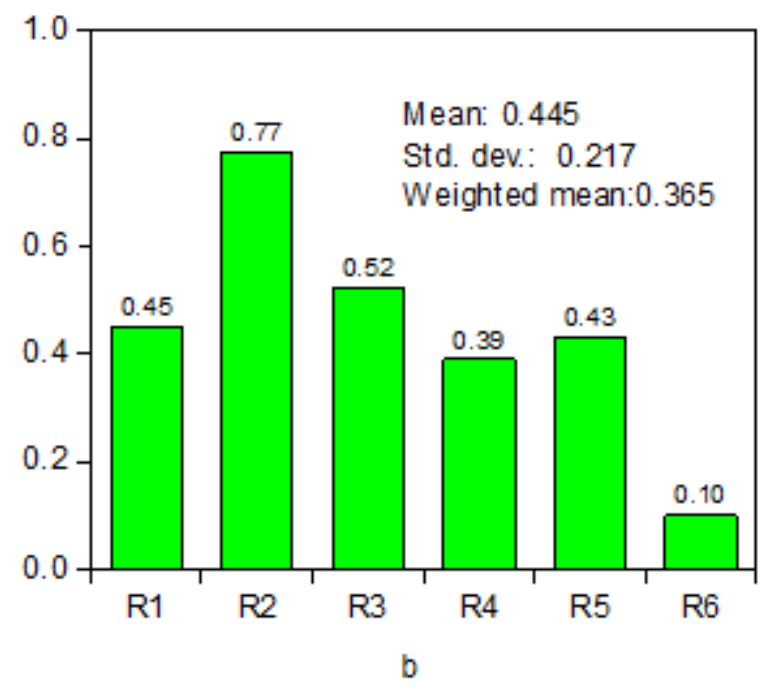


Najibullah Totakhiel

KUNAR

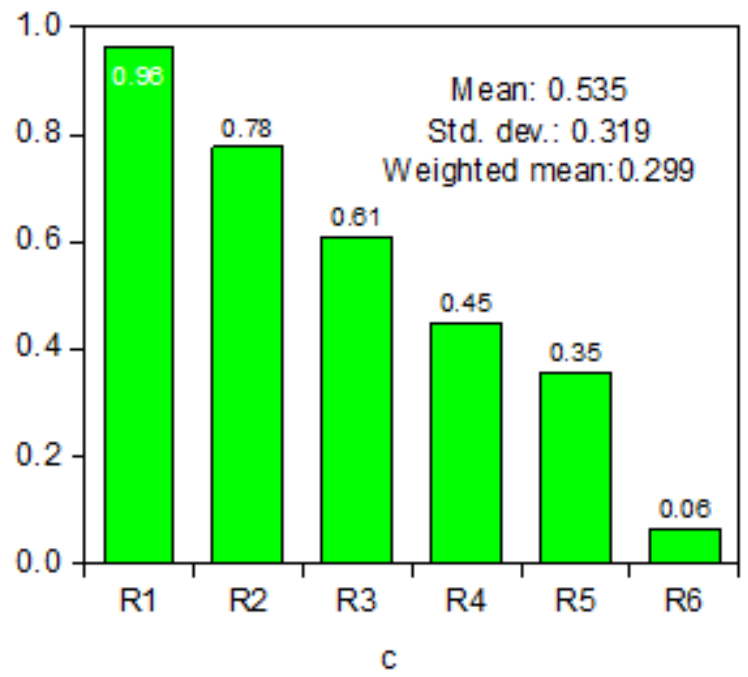

$0.00=$ imparity

$1.00=$ parity
NURISTAN

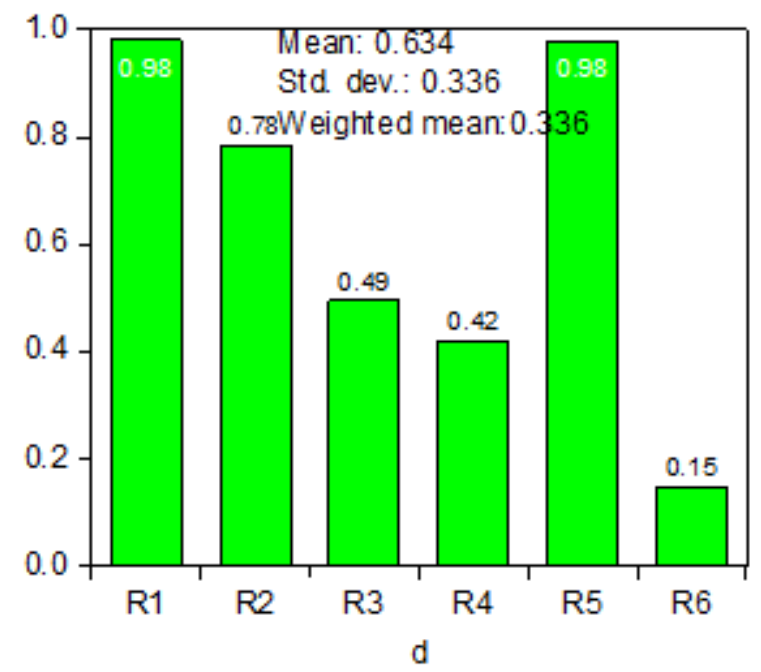

Figure 7: Provincial profiles of EGGI for the ER.

Source: author computation

PAKTIA

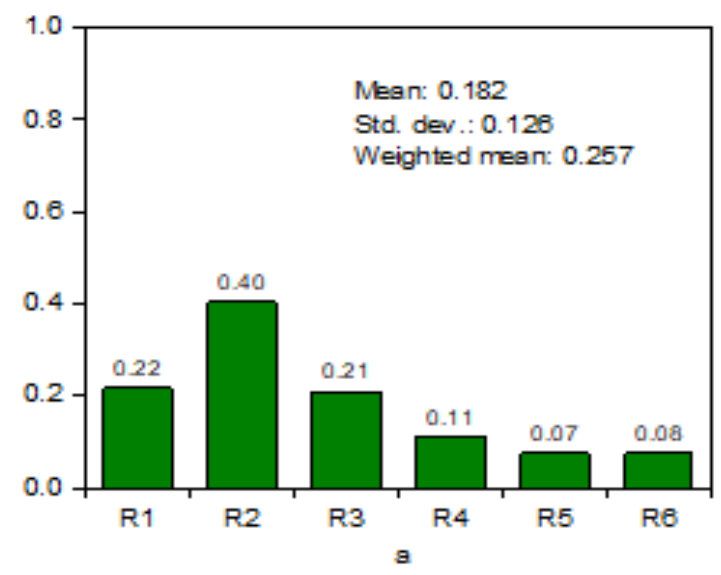

PAKTIKA

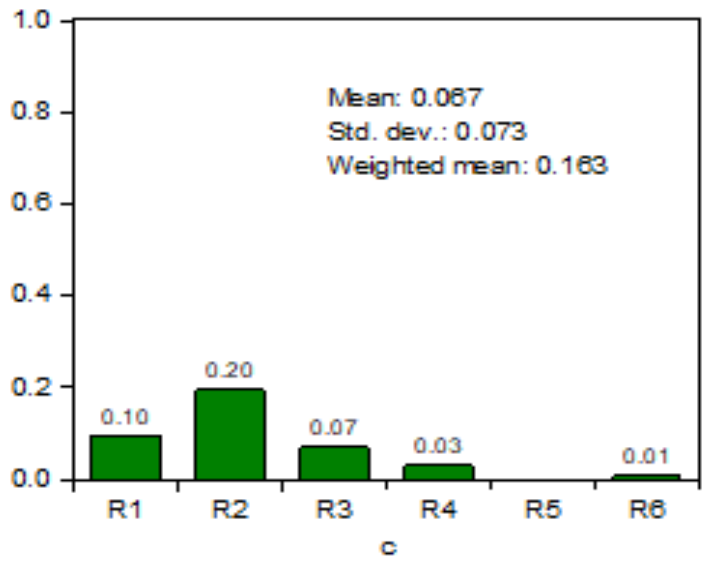

LOGAR

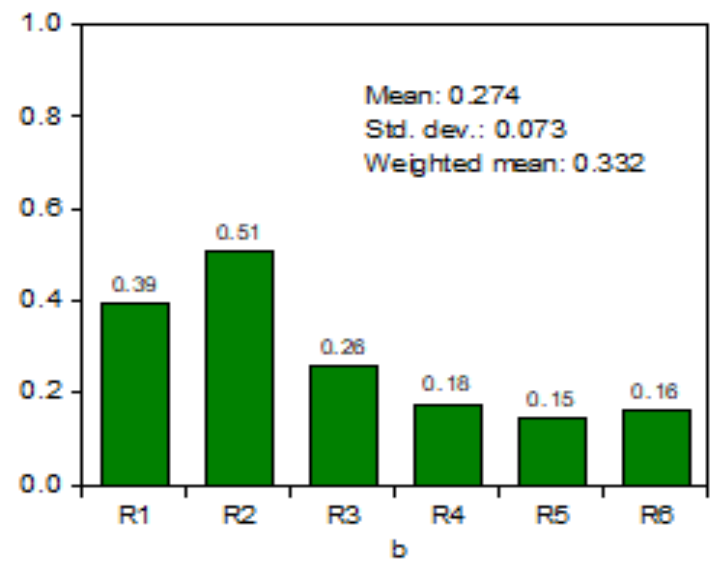

KHOWST

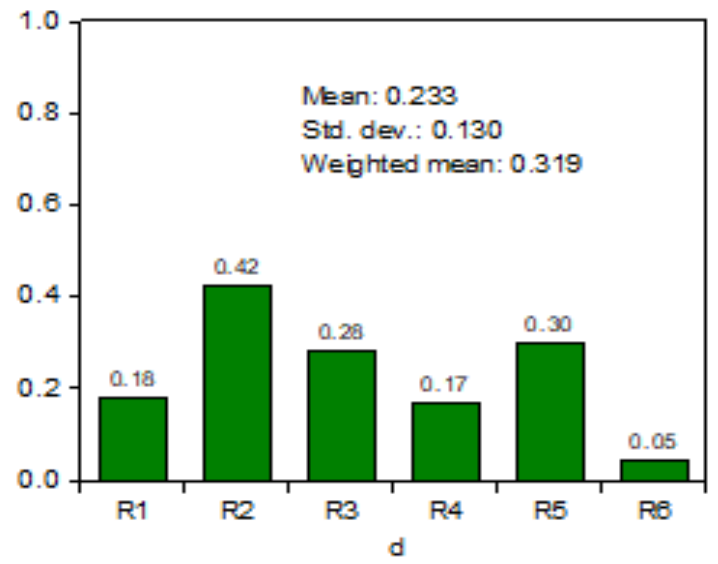


GHAZNI

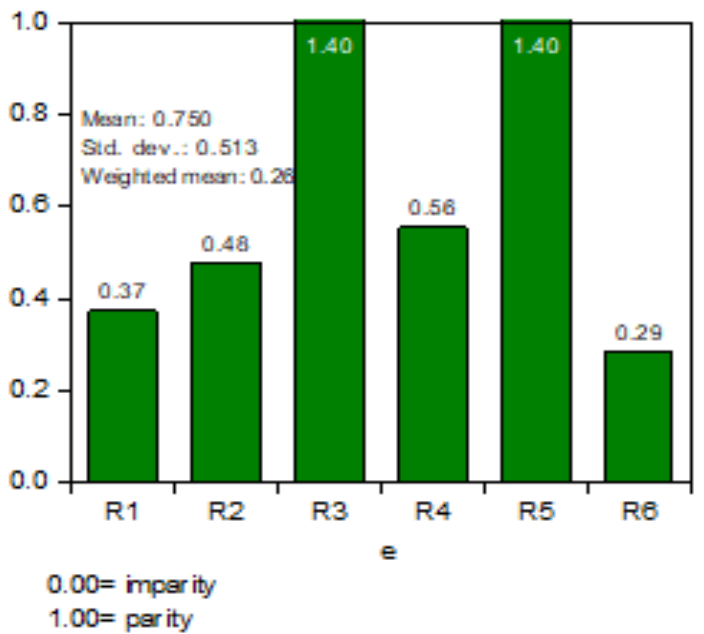

WARDAK

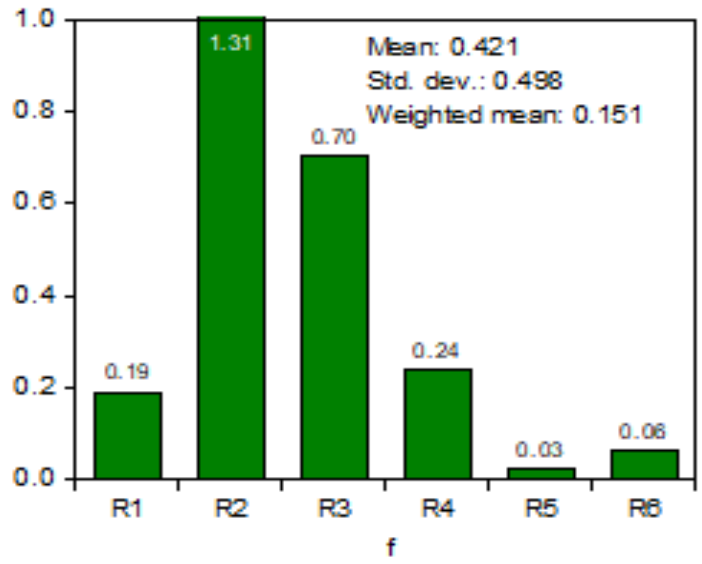

Figure 8: Provincial profiles of the educational gender gap for the SER

Source: author computation

Figure 8 shows the provincial profiles of the gap for the SER. Based on their weighted means or EGGI, the best performing province in the SER is Logar, where the educational gender gap has been closed by $33.2 \%$. Khowst is the second best province, with $31.9 \%$ of the gap having been bridged. The gaps in Ghazni and Paktia province have been closed by $26 \%$ and $25.7 \%$ respectively. The two worst performing provinces are Wardak and Paktika, where the gaps have been closed by only $15.1 \%$ and $16.3 \%$ respectively.

Figure 9 ranks the provinces based on their weighted mean or EGGI. Nangarhar is in first position, with a weighted mean of $42 \%$. Laghman and Nuristan are the second and third best performers, having closed the gap by $36 \%$ and 34\% respectively. Wardak and Paktiaka are the worst performing provinces, with their gaps having been closed by $15 \%$ and $16 \%$ respectively. Logar, Khowst, Kunar, Ghazni and Paktia provinces are in $4^{\text {th }}, 5^{\text {th }}, 6^{\text {th }}$, $7^{\text {th }}$ and $8^{\text {th }}$ position in the rankings respectively.

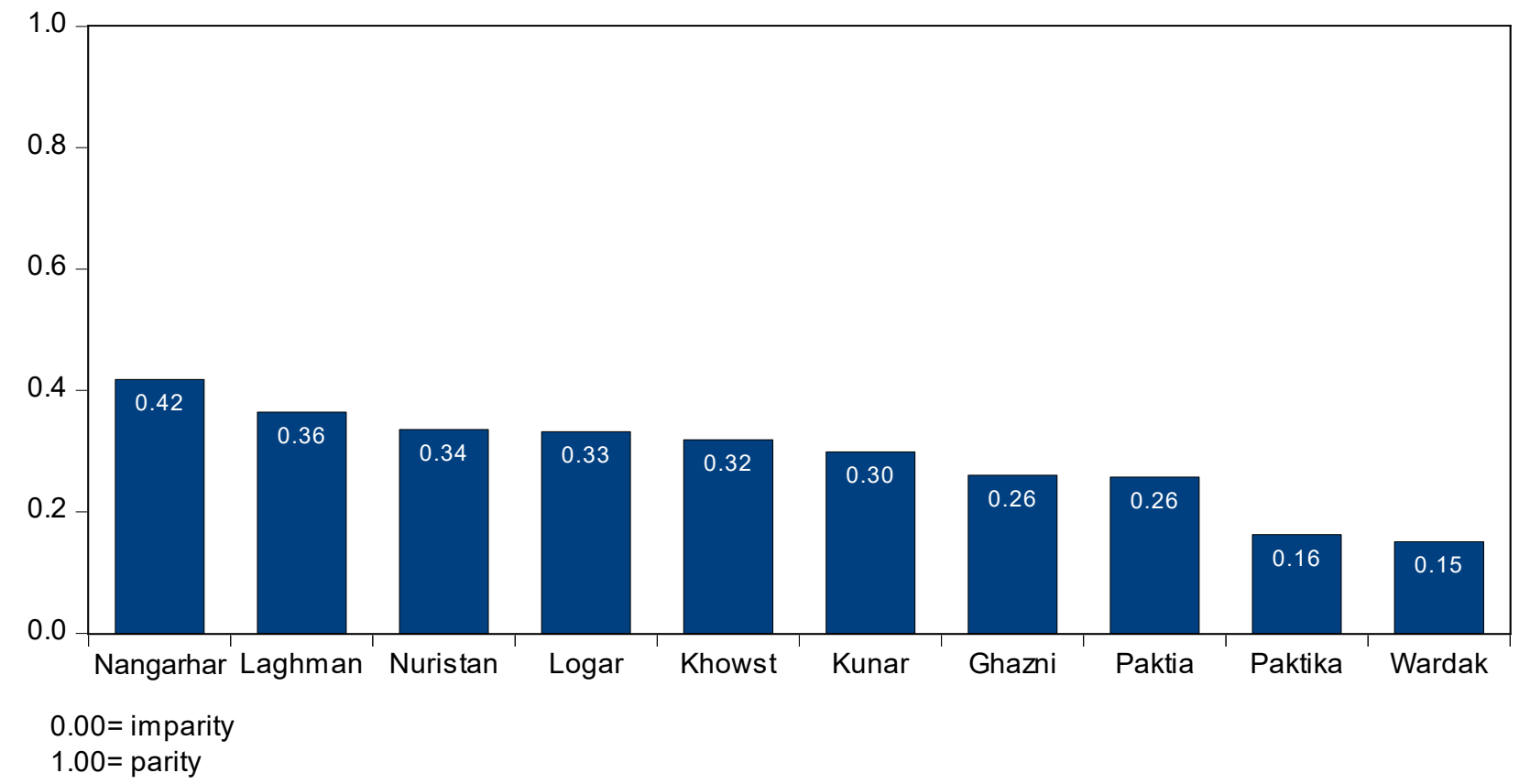

Source: author

Figure 9: Provinces ranked by EGGI 


\subsection{STUDENT-TEACHER RATIO ANALYSIS}

The student-teacher ratio (STR) can be computed from Figures 2 and 3 on page 3 as follows. STR = the number of both male and female students over the number of both male and female teachers:

$$
S T R=\frac{2575494}{48337}=53.28: 1
$$

The female student-teacher ratio (FSTR) can be derived as the number of female students divided by the number of female teachers:

$$
F S T R=\frac{855547}{5647}=151.51: 1
$$

The male student-teacher ratio (MSTR) can be found by dividing the number of male students by the number of male teachers:

$$
\operatorname{MSTR}=\frac{1719941}{42690}=40.29: 1
$$

The gap in this important ratio can be measured as: $\frac{1 / 151.51}{1 / 40.29}=0.264$, which shows that only $26.4 \%$ of the gap in this sub-index has been bridged.

Figure 10 depicts the number of female students per female teacher in each of the provinces. The best performing province is Ghazni, which has one female teacher for every 86 female students. The second-best performing province is Logar, where this ratio is 97:1. Paktika is the worst performing province, with a ratio of 1353:1. The second worst performing province is Khowst, which has a ratio of 462:1.

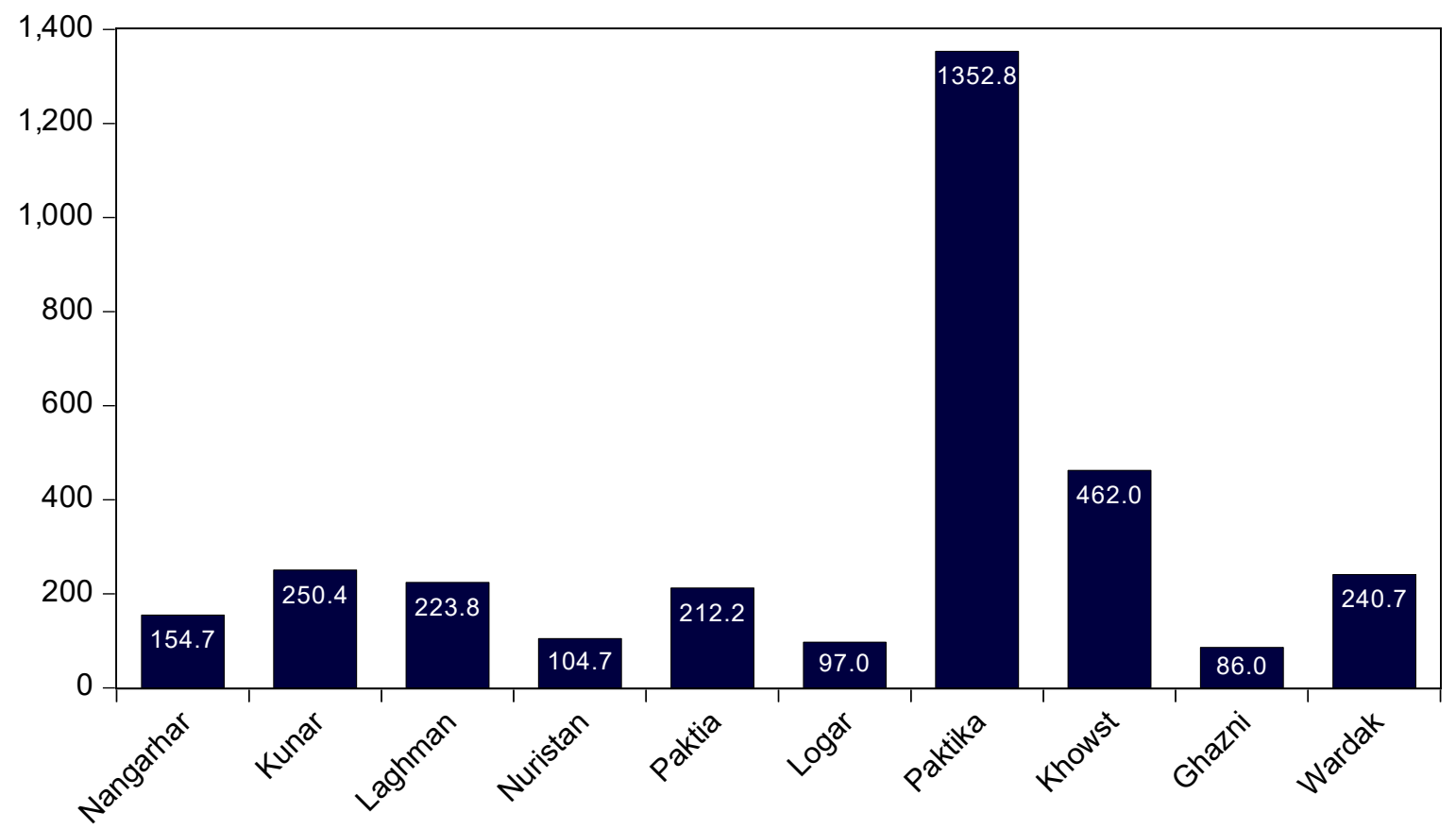

Figure 10: Number of female students per female teacher across the provinces

Source: author computation 
Literacy rate is considered another sub-index of the EGGI. According to a VOA Dari interview with Nurya Nuhzat, a spokeswoman for the Ministry of Education of Afghanistan, the literacy rate in the country is $42 \%$. One third of those who can read are female, and thus 33.3\% of the gender gap has been closed, while $67.7 \%$ of it is yet to be bridged (VOA Dari, September 8, 2019).

\section{DISCUSSION AND CONCLUSION}

One particular societal and economic problem is the persistent gap between male and female access to educational resources and opportunities. This gap not only undermines the quality of life of one half of Afghanistan's population, but also poses a significant risk to the long-term growth and well-being of the country.

The purpose of this research is to measure and analyze the gender gap in education regionally and provincially in both the eastern and southeastern regions of Afghanistan. The study found that there is a large gender gap in education in both regions. The EGGI is approximately 0.30 for both regions. This means there is a gap of $70 \%$ in educational attainment between males and females in these two regions.

The EGGI is 0.35 in the ER and 0.25 in the SER. This indicates that the educational gender gap in the ER is $65 \%$, and in the SER it is 75\%. The gap is thus narrower in the ER than in the SER. At the provincial level, Nangarhar has the smallest gender gap in education of the ten provinces, and Wadak has the largest. The gap size in Nangarhar is $58 \%$, while in Wardak it is $85 \%$.

Across the six sub-indexes of the EGGI, the largest gender disparity is in enrolment in tertiary level education, which has a gap of $69 \%$. The second largest gap is $55 \%$ for the number of male and female schools. There is a similar gap of $53 \%$ in both middle school enrolment and teacher gender ratio. The gaps in enrolment in primary education and secondary education are lower, at $30 \%$ and $43 \%$ respectively.

In addition, the gap in the student-teacher ratio between males and females is $73.6 \%$ in both regions. Moreover, based on the secondary data analysis, there is a $67.7 \%$ gap in literacy rate between males and females across the country.

Further research should be conducted to measure the gap in literacy rate in the provinces studied in this research, as well as to study the causes of the gender gap in these or other regions and provinces of Afghanistan.

\section{SOURCES OF FUNDING}

None.

\section{CONFLICT OF INTEREST}

None.

\section{ACKNOWLEDGMENT}

None.

\section{REFERENCES}

[1] Hausmann, R., Tyson, L. D., and Zahidi, S. (2006). The Global Gender Gap Report, Geneva, Switzerland. Available at: www.weforum.org. Accessed: [March 16, 2019].

[2] UNESCO (2000). Education for All: Meeting Our Collective Commitments. Notes on the Dakar Framework for Action.

[3] VOA Dari (Voice of America Radio, Dari) (September 8, 2019), Nurya Nuhzat, the spokeswomen for the Ministry of Education of Afghanistan.

[4] World Population Review (2019). Afghanistan Population, www.woldpopulationreview.com. Accessed: [October 20, 2019].

[5] WEF (World Economic Forum) (2018). The Global Gender Gap Report, Switzerland. Available at: www.weforum.org. Accessed: [March 17, 2019]. 